\title{
Productive performance of Krškopolje pig breed - Review of preliminary results
}

Batorek Lukač, N. ' ; Tomažin, U. ' ; Škrlep, M. '; Prevolnik Povše, M. ${ }^{1,2}$ and Čandek-Potokar, M. 1,2@

'Agricultural Institute of Slovenia. Ljubliana. Slovenia.

${ }^{2}$ University of Maribor, Faculty of Agriculture and Life Sciences. Maribor. Slovenia.

\begin{abstract}
SUMMARY
Local pig breeds are adapted to specific local environment and fed with various locally available feedstuffs. Besides their genetic merit for agro-biodiversity, they represent the basis for sustainable local pork chains. The aim of the present study was to summarize data already available in the literature on production performance of Slovenian autochthonous pig breed - Krškopolje, which is one of the local pig breeds investigated in the project TREASURE. A collection and review of available literature data on productive traits (growth, carcass and meat quality) of Krškopolje pig breed was carried out. Literature review shows that growth rate of Krškopolje pigs from birth to slaughter is in average $492 \mathrm{~g} /$ day (339-637 g/day; $\mathrm{n}=6$ ). In the studies described in the literature, slaughter was performed at the average age of 293 days (230-360 days; $n=9)$ and $118 \mathrm{~kg}$ live weight (90-145 $\mathrm{kg} ; \mathrm{n}=7)$. Reported average dressing yield was $77.3 \%(71.7-80.2 \% ; n=9)$ and lean meat content $43.5 \%(37.5-47.8 \% ; n=7)$. Backfat thickness measured at the level of the last rib was in average 38 $\mathrm{mm}(28-53 \mathrm{~mm} ; \mathrm{n}=11)$, whereas loin eye area and loin eye fat area were in average 32.6 and 33.0 $\mathrm{cm} 2$, respectively (23.2-41.7; $\mathrm{n}=5$ and 27.7-42.2; $\mathrm{n}=4$; respectively). In the studies reporting meat quality of Krškopolje pigs, $\mathrm{pH} 24 \mathrm{~h}$ post-mortem in Longissimus dorsi muscle was in average 5.46 (5.28-5.60; $n=7)$, drip loss 48 h post-mortem reached $5.1 \%(3.9-6.7 \% ; n=4)$ and intramuscular fat content averaged $3.5 \%(2.7-4.6 \% ; n=6)$. Although studies on Krškopolje pig are scarce, current review gives the first insight on productive performance of this local pig breed.
\end{abstract}

\section{ADDITIONAL KEYWORDS}

Autochthonous breed.

Growth.

Meat quality.
Carcass quality.

\section{Performance produtiva da raça suína Krškopolje - revisão dos resultados preliminares}

\section{RESUMO}

\section{PALAVRAS CHAVE ADICIONAIS}

Crescimento de raça autóctone.

Qualidade da carcaça.

Qualidade da carne.

\section{INFORMATION}

\section{Cronología del artículo.}

Recibido/Received: 14.02.2017

Aceptado/Accepted: 22.06 .2017

On-line: 15.01 .2018

Correspondencia a los autores/Contact e-mail:

meta.candek-potokar@kis.si
As raças suínas locais estão adaptadas a ambientes locais específicos e são alimentadas com vários alimentos disponíveis localmente. Para além do seu interesse genético da óptica da agro-biodiversidade, elas representam uma base para fileiras suínas locais sustentáveis. $\mathrm{O}$ objetivo do presente trabalho é resumir os dados já disponíveis na literatura sobre a performance produtiva da raça autóctone Eslovena, a raça Krškopolje, que é uma das raças estudadas no âmbito do projeto TREASURE. Foi realizada uma pesquisa e revisão da literatura disponível sobre parâmetros produtivos (crescimento, qualidade de carcaça e da carne) de suínos Krškopolje. A revisão da literatura indica que o crescimento do nascimento ao abate é, em média, de 492 $\mathrm{g} /$ dia (339-637 g/dia, $\mathrm{n}=6$ ). $O$ abate é feito, em média, aos 293 dias de idade (230-360 dias; $n=9)$ e a $118 \mathrm{~kg}$ de peso vivo (90-145 kg; $n=7)$. O rendimento de carcaça é, em média, de $77,3 \%(71,7-80,2 \% ; n=9)$ e o teor em tecido magro de $43,5 \%(37,5-47,8 \% ; n=7)$. A espessura da gordura dorsal medida ao nível da última costela é, em média, $38 \mathrm{~mm}$ (28-53mm; $\mathrm{n}=11$ ), enquanto que a área do lombo e a área da gordura do lombo são, em média, 32,6 e $33,0 \mathrm{~cm} 2$, respetivamente $(23,2-41,7 ; n=5$ e $27,7-42,2 ; n=4$, respetivamente). Nos estudos que reportam a qualidade da carne de porcos Krškopolje, o $\mathrm{pH} 24 \mathrm{~h}$ post-mortem no músculo Longissimus dorsi é, em média, $5,46(5,28-5,60 ; n=7)$, a perda por gotejamento "drip loss" $48 \mathrm{~h}$ post-mortem atinge $5,1 \%(3,9-6,7 \% ; n=4)$ e o teor em gordura intramuscular é de $3,5 \%$ $(2,7-4,6 \% ; n=6)$. Embora havendo poucos estudos sobre o porco Krškopolje, a presente revisão dá uma primeira visão sobre a performances produtivas desta raça local.

\section{INTRODUCTION}

Slovenia has only one preserved autochthonous local pig breed, the Krškopolje pig. In the past, this breed was appreciated by farmers because of high fat percentage and good meat quality. However, productivity of these pigs was low and the breed suffered from inbreeding. In the 1970s, when the activities were focused towards the implementation of the modern pig breeds, Krškopolje pigs became almost extinct. In the 1990s, when Slovenian gene bank for endangered domestic animals was established, the population size of Krškopolje pigs was very low, but started to improve after year 2002 (Kastelic \& Čandek-Potokar 2013; p. 206). Literature data on production traits of this pig breed is not abundant, most of publications date after 
Table I. Growth performance, carcass and meat quality traits of Krškopolje pigs (Performance de crescimento e parâmetros de qualidade da carcaça e da carne em suínos Krškopolje).

\begin{tabular}{|c|c|c|c|c|c|}
\hline & No. of studies & Average & Min & Max & References \\
\hline Daily gain from birth to slaughter (g/day) & 6 & 492 & 339 & 637 & $1,5,7,9,13$ \\
\hline \multicolumn{6}{|l|}{ Carcass traits } \\
\hline Age at slaughter (days) & 9 & 293 & 230 & 360 & $1,4,8,9,13$ \\
\hline Weight at slaughter (kg) & 7 & 118 & 90 & 146 & $3,4,5,9,13$ \\
\hline Hot carcass weight (kg) & 9 & 98 & 71 & 121 & $1,3,5,8,11,13$ \\
\hline Carcass yield (\% live weight) & 9 & 77 & 72 & 80 & $2,5,8,9,10,13$ \\
\hline Carcass length a (atlas-os pubis; $\mathrm{cm}$ ) & 9 & 101 & 91 & 107 & $1,5,8,10,13$ \\
\hline Carcass length b (first rib-os pubis; $\mathrm{cm}$ ) & 6 & 85 & 80 & 90 & 8,13 \\
\hline Lean meat content $(\%)$ & 7 & 43.5 & 37.5 & 47.8 & $1,8,11,13$ \\
\hline Ham weight (kg) & 7 & 11.3 & 8.8 & 14.1 & $1,3,4,5,8,13$ \\
\hline Shoulder weight $(\mathrm{kg})$ & 6 & 6.8 & 5.1 & 7.7 & $1,3,5,8,1$ \\
\hline Loin weight (kg) & 6 & 8.8 & 6.3 & 12.7 & $1,3,5,8,1$ \\
\hline Backfat thickness at level of last rib (mm) & 11 & 38 & 28 & 53 & $1,2,3,5,8,10,11,13$ \\
\hline Belly weight (kg) & 3 & 5.5 & 2.6 & 10.2 & 1,8 \\
\hline Belly leanness (1-7) & 3 & 3.2 & 2.7 & 3.6 & 1,8 \\
\hline Loin eye area $\left(\mathrm{cm}^{2}\right)$ & 5 & 32.6 & 23.2 & 41.7 & $1,3,5,10,13$ \\
\hline Loin eye fat area $\left(\mathrm{cm}^{2}\right)$ & 4 & 33.0 & 27.3 & 42.2 & $1,3,5,13$ \\
\hline \multicolumn{6}{|l|}{ Meat quality traits } \\
\hline pH 45 & 6 & 6.03 & 5.82 & 6.49 & $1,4,12,13$ \\
\hline $\mathrm{pH} 24$ & 7 & 5.46 & 5.28 & 5.60 & $1,4,5,12,13$ \\
\hline Subjective colour (1-6) & 8 & 3.7 & 2.3 & 4.3 & $1,3,4,5,12,13$ \\
\hline CIE L* & 5 & 53.0 & 48.1 & 56.2 & $1,4,5,12,13$ \\
\hline CIE a* & 7 & 9.7 & 7.3 & 10.9 & $1,4,5,12,13$ \\
\hline CIE b* & 3 & 4.6 & 1.7 & 7.3 & $1,4,5,12,13$ \\
\hline Drip loss after $48 \mathrm{~h}(\%)$ & 4 & 5.1 & 3.9 & 6.7 & 12,13 \\
\hline Intramuscular fat content (\%) & 6 & 3.5 & 2.7 & 4.6 & $1,3,4,12,13$ \\
\hline Marbling (1-7) & 4 & 3.5 & 3.1 & 4.0 & $1,3,4,13$ \\
\hline
\end{tabular}

*13 - Unpublished data from the TREASURE project 2016

year 2000. The aim of this paper was to make an overview of the available recent data on growth performance, carcass and meat quality traits of Krškopolje breed. Preliminary results from the experiment performed within the TREASURE project were also included.

\section{MATERIAL AND METHODS}

A collection and review of available literature data on productive traits of Krškopolje pig breed was carried out. Growth performance was estimated by means of average daily gain from birth to slaughter, carcass traits by means of age and weight at slaughter, hot carcass weight, carcass yield, carcass length a and, lean meat content, ham, shoulder, and loin weight, backfat thickness at level of last rib, belly weight and leanness, loin eye and loin eye fat area, and meat quality traits by means of $\mathrm{pH}$ at $45 \mathrm{~min}(\mathrm{pH} 45)$ and 24 hours $(\mathrm{pH}$ 24) after slaughter, subjective and objective colour (CIE $\mathrm{L}^{*}, \mathrm{a}^{*}$ and $\mathrm{b}$ ) drip loss after 48 hours, intramuscular fat content and marbling (Krhlin 1959, Gril 1965, Eiselt \& Ferjan 1972, Švajger \& Bregar 1991, Kastelic 2001, Kač
2002, Čandek-Potokar et al. 2003, Žemva et al. 2010, Kovač et al. 2015, Kovač \& Flisar 2015, Žemva et al. 2015, TREASURE project unpublished results).

\section{RESULTS}

Basic data obtained in this review are presented in Table I. The information was obtained from all the available references and the studies varied widely in terms of ages and weight at slaughter, which explains the high amplitude of the values for the growth and quality of meat. In the considered studies, the age of pigs at slaughter was between 230 and 360 days; this denotes lesser intensity which is further substantiated by reported growth rates from birth to slaughter (339-637 g/day). In the considered studies pigs were slaughtered between 90 and $146 \mathrm{~kg}$, i.e. at average live weight $118 \mathrm{~kg}$ and average dressing yield was $77.3 \%$ and lean meat content $43.5 \%$ (SEUROP classification). Backfat thickness at the level of the last rib ranged from 28 to $53 \mathrm{~mm}$ and averaged $38 \mathrm{~mm}$. Compared to modern breeds, Krškopolje breed has lower muscular de- 
velopment as shown by small loin eye area $\left(23-42 \mathrm{~cm}^{2}\right)$. In the few studies reporting meat quality of Krškopolje pigs, $\mathrm{pH}$ measured in Longissimus dorsi muscle at 45 min and $24 \mathrm{~h}$ post-mortem were in average 6.03 and 5.46 , respectively, intramuscular fat content averaged $3.5 \%$, and drip loss $48 \mathrm{~h}$ post-mortem reached $5.1 \%$.

\section{CONCLUSIONS}

Although studies on Krškopolje pig are very scarce, the current review gives the first insight on productive performance of this local pig breed. As for most of the local breeds its productivity is worse compared to modern ones, nevertheless, the breeders were enthusiastic and preserved it in spite of the restrictive policy. Nowadays, this breed is supported by policy mechanisms in order to ensure its preservation. Due to a relatively low population size, preservation of this breed remains the main goal, however, the future perspectives that are also highlighted in the TREASURE project are to make this breed self-sustaining being also one of the best preservation strategies.

\section{ACKNOWLEGMENTS}

The research was conducted within the project TREASURE, which has received funding from the European Union's Horizon 2020 research and innovation programme under grant agreement No 634476. The content of this paper reflects only the author's view and the European Union Agency is not responsible for any use that may be made of the information it contains.

Authors should also acknowledge the core financing of Slovenian Agency of Research (grant P4-0133) and the Ministry of Agriculture, Food and Forestry (V4-1417).

\section{BIBLIOGRAPHY}

Čandek-Potokar, M, Žlender, B, Kramar, Z, Šegula, B, Fazarinc, G, \& Uršič, M 2003, 'Evaluation of Slovene local pig breed Krškopolje for carcass and meat quality', Czech Journal of Animal Science. vol. 48, no. 3, pp. 120-8.

Eiselt, E \& Ferjan, J 1972. 'Proizvodne značilnosti krškopoliskega prašiča' in Znanost in praksa $v$ živinoreji. Biotehniška fakulteta, Ljubljana, Slovenia, pp. 855-63.

Gril, A 1965, 'Razlike o intramuskularni maščobi pri prašičih landrace in krškopoliske pasme', Graduation thesis, University of Liubliana.

Kač, M 2002, 'Kakovost mišičnine krskopoliskega prašiča' Graduation thesis, University of Ljubljana.

Kastelic, A 2001, 'Telesna sestava prašičev krškopoliske pasme' Graduation thesis, University of Ljubljana.

Kastelic, A \& Čandek-Potokar, M 2013, 'Application of quality labels in support of conservation of local breeds - a challenge for Slovenian Krškopolje pig' 8th International Symposium on the Mediterranean Pig, (Acta Agriculturae Slovenica), Biotechnical Faculty, Ljubljana, Slovenia, suppl. 4, pp. 205-9.

Kovač, M \& Flisar, T 2015. 'Rast živali krškopoljske pasme v različnih pogojih reje' in Krškopoliski prašič - od reje do predelave na domu. Biotechnical faculty, Ljubliana, Slovenia, pp. 135-43.

Kovač, M, Urankar, J, Ule, A, \& Malovrh, Š 2015 `Klavne lastnosti krškopoljskih prašičev' in Krškopoliski prašič - od reje do predelave na domu, Biotechnical faculty, Ljubljana, Slovenia, pp. 157-67.

Krhlin, M 1959, 'Razlike med prašiči bele požlahtnjene in črnopasaste krškopoliske pasme $v$ povprečnem letnem priraščanju, odstotku klavnosti in odstotku slanine ter sala', Graduation thesis, University of Ljubljana.

Švajger, G, \& Bregar, D 1991 'Krškopoliski (črnopasasti) prašič' Graduation thesis, University of Ljubljana.

Žemva, M, Malovrh, Š, Levart, A \& Kovač, M 2010. 'Fatty acid composition of meat and adipose tissue from Krškopolje pigs and commercial fatteners in Slovenia', Archiv für Tierzucht, vol. 53, št. 1, pp. 73-84.

Žemva, M, Malovrh, Š \& Kovač, M 2015, 'Kakovost mesa in maščobe krškopoljskih prašičev' in Krškopoljski prašič - od reje do predelave na domu, Biotechnical faculty, Ljubljana, Slovenia, pp. 167-73. 